\title{
Schätzung von genetischen Parametern der Futterver-wertung aus Gruppenmittelwerten - Dargestellt am Beispiel von Legehennen
}

\section{G. HEIL. - Lehrstuhl für Tierzucht Technische Universität München D-80.50 Freising- Weihenstephan.}

Von I 400 Pedigree-Legehennen aus zwei reziproken Kreuzungen, standen die Käfigmittelwerte zur Verfügung. Aus ihnen wurden Heritabilitätswerte und genetische Korrelationen für Legeleistung, Eigewicht und Futterverwertung berechnet. Die Schätzwerte stimmen mit Schätzwerten aus Einzelleistungen recht gut überein. Der Einfluß der Konkurrenz in den Gruppenkäfigen konnte nicht berücksichtigt werden. Für die Futterverwertung wurden bei Typ AB mittlere $\mathrm{h}^{2}$-Werte geschätzt (um 0.4). Für Typ BA waren sie deutlich niedriger (um o.05). Beide Typen unterscheiden sich auch in den Parametern für Eizahl und Eigewicht. Die genetische Korrelation zwischen Futterverwertung und Eizahl ist stark negativ. Futterverwertung und Eigewicht scheinen bei Typ AB kaum, bei Typ BA jedoch negativ korreliert zu sein.

\section{Genetische Korrelationen zwischen Fleischleistungs und Milchleistungsmerkmalen Beim Rind.}

\section{K. Rutzmoser. - Lehrstuhl für Tierzucht, Technische Universität München D-8o5o Freising- Weihenstephan.}

In der Fleischleistungsprüfung waren von 3 I I Vätern 3 o86 männliche Nachkommen geprüft. Von 2 I 5 Vätern waren insgesamt 63707 Töchter-Erstlaktationen bekannt. Mit einer gewichteten Kovarianzanalyse wurden die genetischen Korrelationen errechnet. Alle gefundenen Korrelationen waren klein und im Betrag nicht über 0.20, der Standardfehler war 0.I I-o.I3. Zwischen Größe und Milchleistung wurden leicht positive Korrelationen errechnet. Zunahmen und Milchmenge verhalten sich unabhängig, doch von Milchfettprozent zu Zunahme, Ausbeute und Verfettung wurden leicht positive, zu Pistole Prozent leicht negative Beziehungen gefunden. Es scheint eine gleichsinnige genetisch bestimmte Beziehung des Stoffwechsels für Fettgehalt in Milch und Schlachtkörper zu geben. Für die Zuchtarbeit können Milch- und Fleischleistungsmerkmale als weitgehend unabhängig betrachtet werden, weil die Korrelationen im allgemeinen soklein sind, daß die eine Merkmalsgruppe kaum bedeutsame Information über die andere liefern kann.

\section{A Flexible SySTEM FOR CALCUlating VARIOUS TYPES OF SELFCTION INDEXES}

\section{N. Künzr. - Institute of Animal Production, Swiss Federal Institute of Technology Zurich, Switzerland.}

This paper presents a short and flexible method for computing various types of selection indexes with the same computer program. With given phenotypic and genetic population parameters, indexes including several relatives, traits and measurements per trait, any degree of additive genetic relationship, maternal effects, restrictions and indexes in retrospect may be computed.

\section{REPRODUCTION AND BODYWEIGHT OF MICE} AFTER LONGTERM SELECTION FOR IITTER SIZE

H. Bakker, J. H. Wallinga, R. D. Politiek. - Department of Animal Production Agricultural University Wageningen, Netherlands.

A line founded by selecting 24 biggest litters from a large Swiss random bred mouse population was selected for litter size at birth during 29 generations. Per generation 96 females were mated to 24 males and the 24 biggest litters were selected. Litters were not standardized. Average selection differential was 2.93 young $(i=\mathrm{I} .25)$. Total selection response was an increase from 8 young in the base population to 14 young born in generation 29 of the selection line. Realized heritability was $0.13 \pm 0.01$. Changes in heritability were not significant $(p>0.05)$ during the 29 generations. Correlated responses in number of mice dying from $0-12$ days, and I 2-2 I days, and in body weights at 21 and 56 days were not significant $(p>0.05)$. Litter size 
and litter weight at 12 days and number of mice littering of the 96 exposed per generation increased significantly $(p<0.01)$, while number of days from exposure to male to littering decreased $(p<0.0 \mathrm{I})$.

\author{
EFFECT OF LONGTERM SELECTION FOR NUMBER OF MICE \\ IN THE FIRST LITTER ON SIZE OF SUBSEQUENT LITTERS
}

\title{
J. H. Wallinga, H. Bakker. - Department of Animal Production, Agricultural University Wageningen, Netherlands.
}

Litter size at subsequent parities and total number of litters in a 308 days production period of mice of the $25^{\text {th }}$ generation of a line selected for litter size ( $L$ line) and a control line $\left(C_{3}\right.$ ) were compared. Within the $\mathrm{L}$ line the effect of standardization of litter size at birth to eight young was studied. In both the $L$ and $C_{30}$ lines interval and permanent breeding methods were compared. In interval breeding the males were removed from the female just before littering and were removed from the female just before littering and were returned when the litter was weaned. In permanent breeding the males were left with the females permanently. In permanent breeding the total production of young of the $L$ line was lower than of the $C_{3}$ o line, because the $L$ line was unable to continue the high initial production level (r 4 young) under such an intensive method. In interval breeding total production of young in the $\mathrm{L}$ line was much higher than in $C_{3}$ o because higher litter size of $L$ line was much higher than in $C_{30}$ because higher l!tter size of $L$ line was maintained at subsequent parities. It was speculated that the rapid decrease of litter size of $L$ line dams in permanent breeding was caused by effects of overloading of the uterus. As effects of standardization of litter size were not significant, it was concluded that stress at permanent breeding was caused by shorter intervals combined with big litter size. This lack of effect of standardization suggests that milk production is not the major limiting factor for dams in the $L$ line.

\section{Probleme der Schätzung der Herdenheritabilität am Beispiel DER SCHWARZBUNTZUCHT NIEDERSACHSENS}

E. Bruns, H.-J. Langholz und H. Köther

Die Kenntnis der genetischen Unterschiede zwischen Herden ist für die Wahl geeigneter Zuchtwertschätzverfahren von Bedeutung. Für die niedersächsische Schravzbuntpopulation wurden an einem Material von Färsen, die in der Zeit von Oktober I97I bis Januar I973 abgekalbt hatten und aus 2790 Betrieben stammten, die genetischen Unterschiede zwischen Herden geschätzt. Dabei wurde die von Mc GilliaRD (I952) vorgeschlagene Methode angewendet, die auf dem Vergleich der Varianzkomponenten " Zwischen Herden », hier geschätzt an 9666 väterlichen Halbgeschwistern und $859 \mathrm{I}$ nicht verwandten Tieren, beruht.

Die Ergebnisse deuten für die niedersächsische Schwarzbuntpopulation folgende Situation an :

I. Die Unterschiede zwischen Herden sind zu r6,5 p. Ioo bei der Milchmenge und zu I5, I p. Ioo bei der Fettmenge genetisch bedingt. Für den Fettgehalt konnten keine genetischen Herdenunterschiede festgestellt werden.

2. Beim verstärkten Einsatz von Holstein-Friesian Bullen in einingen Herden muß mit zunehmender genetischer Differenzierung der Herden bei den Milchmengenleistungen gerechnet werden.

3. Das Schätzverfahren nach Mc GILlIARD erwies sich als empfindlich gegenüber einer Interaktion und Korrelation zwischen Herden und Vätern. Beide Effekte wirken antagonistisch auf die Herdenvarianzen und heben sich bei diesem Datenmaterial in ihren Wirkungen in etwa gegenseitig auf.

4. Für die Zuchtwertschätzung wirdeine Korrektur für das genetische Herdenniveau über den Zuchtwert der in einer Herde eingesetzten Väter als wirksamer angesehen als die bisher praktizierte Korrektur. 